\title{
High-efficiency transformation and gene inactivation in Streptococcus suis type 2
}

\author{
Hilde E. Smith, ${ }^{1}$ Henk J. Wisselink, ${ }^{2}$ Uri Vecht, ${ }^{2}$ Arno L. J. Gielkens ${ }^{1}$ and \\ Mari A. Smits ${ }^{1}$
}

Author for correspondence: Hilde Smith. Tel: +313200 73319. Fax: +313200 73473.

e-mail:m.a.smits@cdi.agro.nl

Departments of Molecular Biology' and Bacteriology2, Institute for Animal Science and Health, PO Box 65, 8200 AB Lelystad, The Netherlands

\begin{abstract}
An efficient electrotransformation system for Streptococcus suis type 2 is described. It is demonstrated that vectors based on the broad-host-range plasmid pWVO1 replicate in S. suis type 2. Transformation efficiencies of about $10^{7}$ transformants per $\mu \mathrm{g}$ of plasmid DNA could be obtained. Derivatives of plasmid pBR322 containing S. suis chromosomal DNA did not replicate but integrated into the chromosome. Southern hybridization analysis revealed that double as well as single cross-over integration events had occurred. Double cross-over events occurred at a frequency of about $15 \%$. With these transformation and integration systems, recombinant DNA technology can now be applied to this important pathogenic species.
\end{abstract}

Keywords: transformation, homologous recombination, double and single cross-over integrations, gene amplification

\section{INTRODUCTION}

Streptococcus suis type 2 is an important cause of meningitis, septicaemia, arthritis and sudden death in young pigs (Clifton-Hadley, 1983; Vecht et al., 1985), and of meningitis in humans (Arends \& Zanen, 1988). During the last few years $S$. suis type 2 infections have become a major problem in almost all countries with an intensive pig industry. So far, little is known about the pathogenesis and the epidemiology of $S$. suis type 2 infections.

Strains of S. suis type 2 may differ in virulence (Vecht et al., 1989). We previously identified two proteins, muramidasereleased protein (MRP) and extracellular factor (EF), of $S$. suis type 2 that seem to be associated with pathogenicity (Vecht et al., 1991). To study the role of MRP and EF in the pathogenesis of $S$. suis type 2 infections, isogenic mutants impaired in the expression of MRP and EF could be of great benefit. To construct these mutants, a system for the efficient introduction of exogenous DNA into $S$. suis type 2 is required. Moreover, the expression of an antibiotic-resistance gene that is suitable for selection of transformants and homologous recombination in $S$. suis type 2 is necessary. So far, transformation systems and gene replacements have not been described for this organism. At present, electrotransformation is the system most widely used to efficiently introduce DNA into

Abbreviations: EF, extracellular factor; MRP, muramidase-released protein.
Gram-negative (Dower et al., 1988; Miller et al., 1988; Sreenivasan et al., 1991), and Gram-positive bacteria (Van der Lelie et al., 1988; Holo \& Nes, 1989; Dunny et al., 1991). In the present paper we show that electrotransformation can also be used to efficiently introduce plasmid DNA into $S$. suis type 2 . To develop the electroporation system, plasmid vectors which replicate in $S$. suis were required. Here, we report that plasmids based on the broad-host-range plasmid pWVO1 replicate in $S$. suis. In addition, by using non-replicative plasmids, chromosomal integration and double cross-over recombination events were obtained.

\section{METHODS}

Bacterial strains and growth conditions. The virulent strains D282 and 10 of S. suis type 2 (Vecht et al., 1989, 1992) were used as parent strains for the construction of the mutants. Escherichia coli strain JM101 (Messing, 1979) was used as host for recombinant plasmids. S. suis strains were grown in ToddHewitt broth (code CM189, Oxoid), and plated on Columbia agar blood base (code CM331, Oxoid) containing $6 \%(\mathrm{v} / \mathrm{v})$ horse blood. Antibiotics were added to the plates at the following concentrations: chloramphenicol, $5 \mu \mathrm{g} \mathrm{ml}^{-1}$; erythromycin, $1 \mu \mathrm{g} \mathrm{ml}^{-1}$; and spectinomycin, $100 \mu \mathrm{g} \mathrm{ml}^{-1}$. E. coli strains were grown in Luria broth (Miller, 1972) and plated on Luria broth containing $1.5 \%(\mathrm{w} / \mathrm{v})$ agar. Antibiotics were added to $E$. coli cultures or plates at the following concentrations: ampicillin, $50 \mu \mathrm{g} \mathrm{ml}^{-1}$; chloramphenicol, $5 \mu \mathrm{g} \mathrm{ml}^{-1}$; erythromycin, $100 \mu \mathrm{g} \mathrm{ml}^{-1}$; and spectinomycin, $50 \mu \mathrm{g} \mathrm{m}^{-1}$.

Plasmids. The plasmids used in this study are shown in Table 1. 
Table 1. Plasmids

\begin{tabular}{|c|c|c|}
\hline Plasmid & Relevant properties* & Source or reference \\
\hline pWVO1 & Cryptic plasmid of Lactococcus lactis subsp. cremoris Wg2 & Kok et al. (1984) \\
\hline pGL3 & Replication functions of $\mathrm{pWVO} 1, \mathrm{Cm}^{R} \mathrm{Km}^{R}$ & Kindly provided by $\mathrm{J}$. Kok \\
\hline pGA14 & Replication functions of pWVO1, $\mathrm{Em}^{\mathbf{R}}$ & Perez-Martinez et al. (1992) \\
\hline pGA14-spc & Replication functions of $\mathrm{pWVO} 1, \mathrm{Em}^{\mathrm{R}} \mathrm{Spc}^{\mathrm{R}}$ & This work \\
\hline pKUN19 & Replication functions of $\mathrm{pUC}, \mathrm{Amp}^{\mathrm{R}}$ & Konings et al. (1987) \\
\hline pKUN19-spc & Replication functions of $\mathrm{pUC}, \mathrm{Amp}^{\mathrm{R}} \mathrm{Spc}^{\mathrm{R}}$ & This work \\
\hline pMR11 & pKUN19 containing the entire $m r p$ gene & Smith et al. (1992) \\
\hline pMR17 & pMR11 with the $s p c^{R}$ gene inserted into the Scal site of the $m r p$ gene & This work \\
\hline pMR18 & pMR11 with the $s p c^{\mathrm{R}}$ gene inserted into the $S c a I$ site of the $m r p$ gene & This work \\
\hline pDL282 & Replication functions of $\mathrm{pBR} 322$ and $\mathrm{pVT} 736-1, \mathrm{Amp}^{\mathrm{R}} \mathrm{Spc}^{\mathrm{R}}$ & Sreenivasan et al. (1991) \\
\hline
\end{tabular}

* Amp ${ }^{R}$, ampicillin resistant; $\mathrm{Cm}^{\mathbf{R}}$, chloramphenicol resistant; $\mathrm{Em}^{\mathbf{R}}$, erythromycin resistant; $\mathrm{Spc}^{\mathrm{R}}$, spectinomycin resistant.

DNA manipulations were performed by standard techniques (Sambrook et al., 1989). pGL3 contains the replication functions of pWVO1 (Kok et al., 1984), the alacZ gene of M13mp10 (Messing, 1983), the chloramphenicol-resistance gene of pC194 (Horinouchi \& Weisblum, 1982) and a kanamycin-resistance gene of Enterococcus faecalis (Trieu-Cuot \& Courvalin, 1983). To disrupt the mrp gene in pMR11 (Smith et al., 1992), the $s p c^{\mathrm{R}}$ gene from pDL282 (Sreenivasan et al., 1991) was inserted into the Scal site within the mrp gene. Therefore, we digested pDL282 with HindIII and partially with KpnI. The 1200 bp HindIII-KpnI fragment containing the $s p c^{\mathrm{R}}$ gene was isolated. The restriction sites were filled in with Klenow enzyme and the fragment was ligated to pMR11, which was partially digested with $S_{c a I}$. In pMR18, the $m r p$ and the $s p c^{R}$ genes are transcribed in the same direction (see Fig. 1a), whereas in PMR17 they are transcribed in opposite directions (Fig. 1b). In pKUN19-spc the $1200 \mathrm{bp}$ HindIII-KpnI fragment containing the $s p c^{\mathbb{R}}$ gene was ligated to HindIII- and KpnI-digested pKUN19. To construct pGA14spc, we ligated the $1200 \mathrm{bp}$ HindIII-KpnI fragment containing the $s p c^{\mathbf{R}}$ gene to the largest HindIII-KpnI fragment of pGA14 (Perez-Martinez et al., 1992), which contained the replication functions. Ligation mixtures were used to transform $E$. coli JM101 and spectinomycin-resistant colonies were selected.

Electrotransformation of S. suis type 2. Overnight cultures in Todd-Hewitt broth were diluted 50-fold in $200 \mathrm{ml}$ fresh Todd-Hewitt broth supplemented with $40 \mathrm{mM}$ DL-threonine. Cultures were incubated for a further $3 \mathrm{~h}$ at $37^{\circ} \mathrm{C}$ to an $\mathrm{OD}_{600}$ of about $0 \cdot 4$. Cells were then harvested by centrifugation and washed twice with $20 \mathrm{ml}$ ice-cold double-distilled water, twice with $20 \mathrm{ml}$ ice-cold $0.3 \mathrm{M}$ sucrose and once with $20 \mathrm{ml}$ ice-cold $0.3 \mathrm{M}$ sucrose plus $15 \%(\mathrm{v} / \mathrm{v})$ glycerol. The cells were resuspended in $1 \mathrm{ml} 0.3 \mathrm{M}$ sucrose plus $15 \%$ glycerol and were either used directly for electrotransformation or stored at $-80^{\circ} \mathrm{C}$. Portions $(50 \mu \mathrm{l})$ of these cell suspensions were mixed with $5 \mu \mathrm{g}$ plasmid DNA at $0{ }^{\circ} \mathrm{C}$. The mixtures were transferred int prechilled sterile Gene Pulser cuvettes (inter-electrode distance $0.2 \mathrm{~cm}$; Bio-Rad). Electrotransformations were done using the Bio-Rad Gene Pulser apparatus. Pulses were achieved with a setting of $25 \mu \mathrm{F}, 2.5 \mathrm{kV}$ and $200 \Omega$. This setting resulted in a time constant ranging from 4.6 to $5.2 \mathrm{~ms}$. After the electric pulse the cells were diluted immediately in $1 \mathrm{ml}$ Todd-Hewitt broth plus $0.3 \mathrm{M}$ sucrose and incubated for $2 \mathrm{~h}$ at $37^{\circ} \mathrm{C}$. They were then plated on agar plates containing selective antibiotics.

Detection of MRP and EF by Western blotting and ELISA. For Western blot analysis, proteins were separated by SDS-PAGE
(Laemmli, 1970) with $4 \%$ stacking gels and $6 \%$ separating gels. The separated proteins were transferred to nitrocellulose in a Semi-Dry transfer cell (Bio-Rad). To detect specific proteins the blots were incubated with polyclonal antibodies directed against MRP and EF (Vecht et al., 1991). Bound antibodies were visualized with anti-rabbit sera conjugated with alkaline phosphatase (Zymed Laboratories) as described by Sambrook et al. (1989).

The presence of MRP and EF in $S$. suis culture supernatants was determined with MRP- and EF-specific double-antibody sandwich ELISAs as described by Vecht et al. (1993).

Southern blotting and hybridization. Chromosomal DNA was isolated as described by Sambrook et al. (1989). DNA fragments were separated on $0.8 \%$ agarose gels and transferred to ZetaProbe GT membranes (Bio-Rad) as described by Sambrook $e t$ al. (1989). DNA probes were labelled with $\left[\alpha-^{32} \mathrm{P}\right] \mathrm{dCTP}(3000 \mathrm{Ci}$ $\mathrm{mmol}^{-1}$, $111 \mathrm{TBq} \mathrm{mmol}^{-1}$; Amersham) by use of a randomprimed labelling kit (Boehringer). The DNA on the blots was hybridized at $65^{\circ} \mathrm{C}$ with DNA probes as recommended by the supplier of the Zeta-Probe membranes. After hybridization, the membranes were washed twice with a solution of $40 \mathrm{mM}$

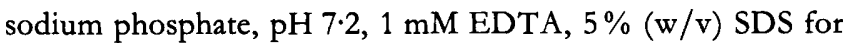
$30 \mathrm{~min}$ at $65^{\circ} \mathrm{C}$ and twice with a solution of $40 \mathrm{mM}$ sodium phosphate, $\mathrm{pH} 7 \cdot 2,1 \mathrm{mM}$ EDTA, $1 \% \mathrm{SDS}$ for $30 \mathrm{~min}$ at $65^{\circ} \mathrm{C}$.

\section{RESULTS}

\section{Electrotransformation of S. suis type 2}

In order to develop an electrotransformation system for $S$. suis type 2 , plasmids which replicate in $S$. suis type 2 were required. Since such plasmids were not available we tested whether pWVO1-based-host-range plasmids could be used. Plasmid pWVO1 was originally isolated from Lactococcus lactis subsp. cremoris Wg2 (Kok et al., 1984) and is able to replicate in E. coli as well as in a considerable number of Gram-positive bacteria (Bron, 1990; Kok, 1991). Therefore we assumed that pWVO1-based plasmids may also replicate in S. suis. Because the virulent $S$. suis type 2 strains D282 and 10 are sensitive to both chloramphenicol and spectinomycin, and strain 10 is sensitive to erythromycin as well, we used the plasmids pGL3, pGA14 and pGA14-spc (Table 1) in our initial 
Table 2. Electrotransformation frequencies

\begin{tabular}{|lccccc|}
\hline \multirow{2}{*}{$\begin{array}{l}\text { S. suis } \\
\text { strain }\end{array}$} & \multicolumn{5}{c|}{ Electrotransformation frequency* } \\
\cline { 2 - 6 } & $\begin{array}{c}\text { pGL3 } \\
\left(\mathbf{C m}^{\mathbf{R}}\right)\end{array}$ & $\begin{array}{c}\text { pGA14 } \\
\left(\mathbf{E m}^{\mathbf{R}}\right)\end{array}$ & $\begin{array}{c}\text { pGA14-spc } \\
\left(\mathbf{S p c}^{\mathbf{R}}\right)\end{array}$ & $\begin{array}{c}\text { pKUN19-spc } \\
\left(\mathbf{S p c} \mathbf{R}^{\mathbf{R}}\right)\end{array}$ & $\begin{array}{c}\text { No DNA } \\
\left(\mathbf{S p c}^{\mathbf{R}}\right)\end{array}$ \\
\hline D282 & $1 \cdot 5 \times 10^{4}$ & $\mathrm{ND}$ & $10^{7}$ & 30 & 30 \\
10 & 60 & $2 \cdot 5 \times 10^{4}$ & $3 \times 10^{6}$ & 20 & 20 \\
\hline
\end{tabular}

* Number of transformants per $\mu \mathrm{g}$ DNA. The numbers represent data of one representative experiment. ND, Not determined.

$\dagger$ Number of colonies derived from a control transformation experiment.

Table 3. Electrotransformation of S. suis type 2 strains with non-replicative plasmids

\begin{tabular}{|llccc|}
\hline $\begin{array}{l}\text { S. suis } \\
\text { strain }\end{array}$ & Plasmid & $\begin{array}{c}\text { Electrotransformation } \\
\text { frequency* }\end{array}$ & $\begin{array}{c}\text { No. of Spc } \mathbf{R}^{\mathbf{R}} \text { tfm. } \\
\text { tested for MRP } \\
\text { production }\end{array}$ & $\begin{array}{c}\text { No. of MRP- } \\
\text { Spc }^{\mathbf{R}} \text { tfm. }\end{array}$ \\
\hline D282 & pGA14-spc & $3 \times 10^{6}$ & & \\
10 & pGA14-spc & $1 \times 10^{6}$ & & \\
D282 & pKUN19-spc & 30 & & \\
10 & pKUN19-spc & 20 & 36 & $5(13.8 \%)$ \\
D282 & pMR17 & 450 & & \\
10 & pMR17 & ND & 72 & $12(16 \cdot 7 \%)$ \\
D282 & pMR18 & 500 & 72 & $12(16 \cdot 7 \%)$ \\
10 & pMR18 & 250 & & \\
\hline
\end{tabular}

* Number of transformants $(\mathrm{tfm}$.) per $\mu \mathrm{g}$ DNA. The numbers represent data of one representative experiment. ND, Not done.

experiments. The plasmids were isolated from E. coli and subsequently used for electrotransformation of strains D282 and 10. Chloramphenicol- and erythromycinresistant transformants were obtained at a low frequency after incubating the plates for $40 \mathrm{~h}$ at $37^{\circ} \mathrm{C}$ (Table 2). Spectinomycin-resistant transformants, however, were obtained after $16 \mathrm{~h}$ at $37^{\circ} \mathrm{C}$. Moreover, the latter transformants occurred at a high frequency (Table 2). We confirmed the presence of the donor plasmids in the transformants by DNA isolation and Southern hybridization (results not shown). These data show that $S$. suis type 2 cells can be electrotransformed at a high frequency, that plasmids derived from pWVO1 replicate in $S$. suis type 2 and that the spectinomycin-resistance gene from Enterococcus faecalis is a suitable selectable marker for $S$. suis type 2 . In contrast to the pWVO1-derived plasmids, plasmids based on the replication functions of pUC did not produce spectinomycin-resistant colonies above background levels (Table 2).

To obtain optimal electrotransformation efficiencies we varied conditions for growth of the cells, washing procedures and the electric field strength. None of these variations increased the transformation efficiencies substantially. In a number of streptococcal species, the transformation efficiency was significantly increased when the cells were grown in the presence of glycine (Holo \& Nes, 1989; Dunny et al., 1991). The growth of $S$. suis cells, however, was strongly inhibited by glycine (concentrations $>0.25 \%$ ). In addition, the cells frequently lysed during electrotransformation when grown with glycine. If the cells were stored at $-80^{\circ} \mathrm{C}$ prior to the electrotransformation, no significant effect on the transformation efficiency was observed. Therefore, we could use frozen electro-competent cells from one batch in successive experiments.

\section{Chromosomal integration}

To study whether pUC-based plasmids could be used to obtain chromosomal integrations in $S$. suis type 2, we constructed plasmids in which the mrp gene of $S$. suis was disrupted by the insertion of the $s p c^{\mathrm{R}}$ gene (LeBlanc et al., 1991 ; Sreenivasan et al., 1991). We previously described the cloning of the mrp gene into the pUC-derived plasmid vector pKUN19 (Smith et al., 1992). In pMR18 the distupted $m r p$ and the $s p c^{\mathrm{R}}$ gene are transcribed in the same direction. In pMR17 these genes are transcribed in opposite directions. We electrotransformed strains D282 and $10\left(\mathrm{MRP}^{+} \mathrm{EF}^{+}\right)$with pMR17 and pMR18. To determine the electrocompetence of the cells, we also transformed them with pGA14-spc, a plasmid that is able 
(a)

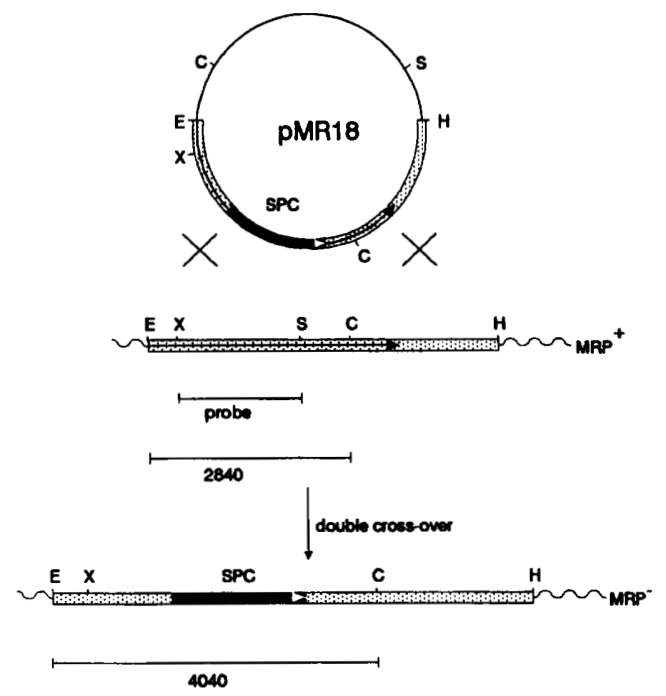

(b)
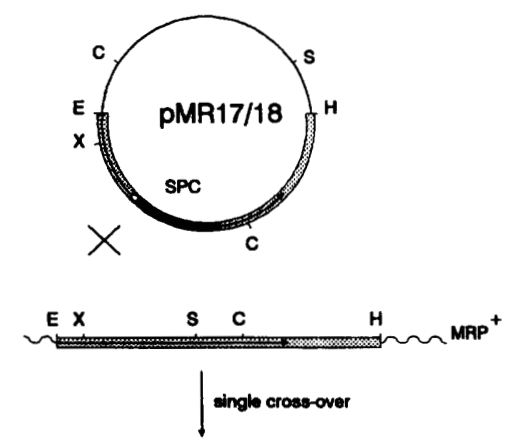

(c)
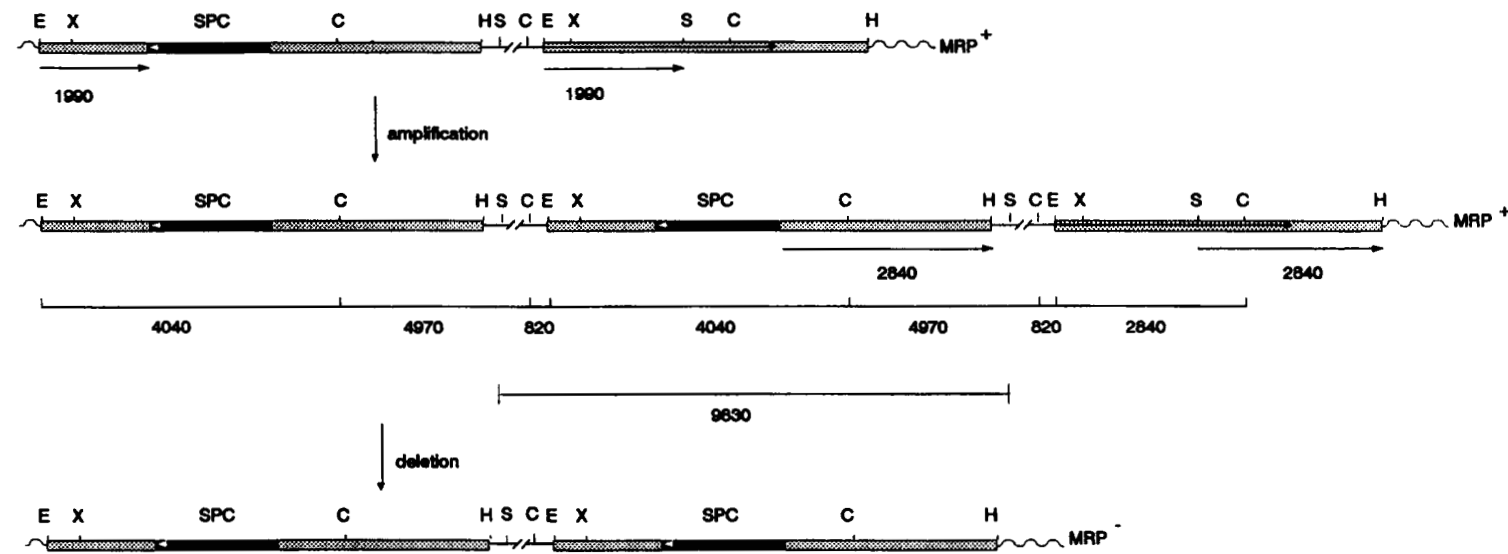

to replicate in $S$. suis. With strain D282 we obtained $3 \times 10^{6}$ transformants per $\mu \mathrm{g}$ pGA14-spc DNA and with strain 10 we obtained $1 \times 10^{6}$ transformants per $\mu \mathrm{g}$ pGA14-spc DNA (Table 3). After transformation with the non-replicative plasmids pMR17 and PMR18 we obtained 250-500 transformants per $\mu$ g DNA (Table 3). In transformations with pMR18, transformants were obtained after a $16 \mathrm{~h}$ incubation period at $37^{\circ} \mathrm{C}$. In transformations with pMR17, however, transformants were obtained after $40 \mathrm{~h}$ at $37^{\circ} \mathrm{C}$. Only low numbers of colony-forming units were obtained after transformation of $S$. suis cells with pKUN19-spc, a plasmid that is unable to replicate in $S$. suis and does not contain chromosomal $S$. suis sequences (Table 3). Based on these data we surmised
Fig. 1. Schematic representation of the chromosomal structures after double (a) and single (b) cross-over recombination events between pMR 18 and PMR17 and the chromosome of S. suis type 2 strain D282. (c) Schematic representation of the amplification due to the 1990 bp repeats and of the deletion of the intact copy of the mrp gene by recombination between the 2840bp repeats. 國, Chromosomal S. suis type 2 DNA containing the mrp gene; $\square, s p c^{R}$ gene; pKUN19 DNA; m, chromosome of S. suis type 2. C, Clal; E, EcoRI; H, HindIII; S, Scal; X, Xbal. The sizes of the EcoRI-Clal and Scal fragments are indicated in bp. that the $\mathrm{Spc}^{\mathrm{R}}$ transformants obtained with $\mathrm{pMR} 17$ and pMR18 were the result of integration of the plasmid into the chromosome by homologous recombination. Two classes of $\mathrm{Spc}^{\mathrm{R}}$ recombinants can be envisaged (Leenhouts et al., 1990, 1991; Fig. 1): a double cross-over recombination event (Fig. 1a) is expected to produce an MRPphenotype, and plasmid integration via a single crossover recombination (Fig. 1b) is expected to result in the original $\mathrm{MRP}^{+}$phenotype (the entire $m r p$ gene and an inactivated $m r p$ gene are present). To differentiate between these two types of recombinants, we measured the production of MRP in a number of $\mathrm{Spc}^{\mathbf{R}}$ transformants by means of an MRP-specific ELISA (Vecht $e$ t al., 1993). As a control we measured the production of EF by an EF- 
(a)

(b)

(c)

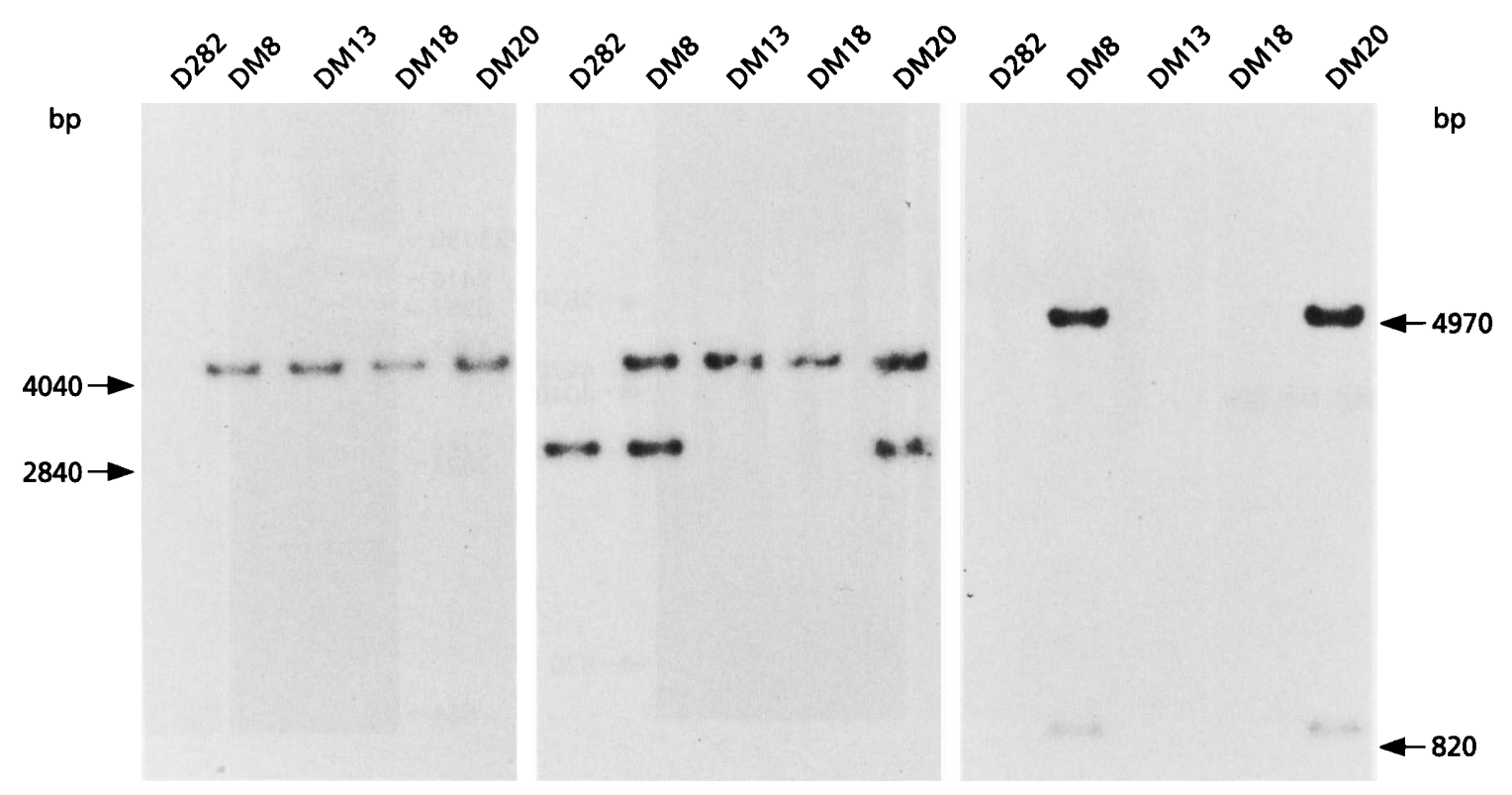

Fig. 2. Southern blots of chromosomal DNA of S. suis strain D282 and various MRP $^{-}$strains obtained after transformation of strain D282 with pMR18. Chromosomal DNA was digested with EcoRI and Clal. The probes used were: (a) a $1200 \mathrm{bp}$ Kpnl-HindIII fragment containing the $s p c^{R}$ gene, (b) an internal $1210 \mathrm{bp}$ Xbal-Scal fragment of the $m r p$ gene, and (c) pKUN19. Strain designations are indicated above the lanes.

specific ELISA. As expected, all $\mathrm{Spc}^{\mathbf{R}}$ transformants produced EF. In contrast, about $15 \%$ of the $\mathrm{Spc}^{\mathrm{R}}$ transformants tested did not produce MRP (Table 3). This suggests that in about $15 \%$ of the integrations the original $m r p$ gene was replaced by the interrupted $m r p$ gene.

\section{Characterization of mutants by Southern hybridization}

We analysed the chromosomal structure of a number of $\mathrm{Spc}^{\mathrm{R}} \mathrm{MRP}^{-}$mutants by Southern hybridization. Fig. 2 shows the results of Southern hybridization with four $\mathrm{Spc}^{\mathbf{R}} \mathrm{MRP}^{-}$mutants that were obtained after transformation of strain D282 with pMR18. Chromosomal DNA isolated from the mutant strains and the recipient strain D282 was digested with EcoRI and ClaI. After electrophoresis, these samples were hybridized with three different probes: a fragment containing the $s p c^{\mathrm{R}}$ gene, an $X b a \mathrm{I}-S c a \mathrm{I}$ fragment located within the coding region of the $m r p$ gene, and plasmid pKUN19. As expected, DNA of the four transformants hybridized with the $s p c^{\mathbf{R}}$ gene (Fig. 2a). In strain D282 a 2840 bp EcoRI-ClaI fragment hybridized with the $m r p$ probe (Fig. $2 \mathrm{~b}$ ). This fragment was absent in the mutant strains DM13 and DM18. In these two mutants the mrp probe hybridized with a 4040 bp EcoRI-ClaI fragment. This fragment also hybridized with the $s p c^{\mathrm{R}}$ gene probe (compare Figs $2 \mathrm{a}$ and 2b). Strains DM13 and DM18 did not hybridize with pKUN19 (Fig. 2c), and therefore did not contain vector sequences. These results strongly suggest that in DM13 and DM1 18 the $m r p$ gene was replaced by the inactivated mrp gene via a double cross-over recombination event (Fig. 1a).

In the digests of mutants DM8 and DM20 the $m r p$ probe hybridized with both the $2840 \mathrm{bp}$ and the $4040 \mathrm{bp}$ EcoRI-ClaI fragments (Fig. 2b). Apparently, these mutants contain a copy of the original mrp gene as well as a copy of the inactivated $m r p$ gene. Moreover, in strains DM8 and DM20 a 4970 bp and a 820 bp EcoRI-ClaI fragment hybridized with pKUN19 (Figs 1 and 2c). This indicates that these strains also contained vector sequences. These data indicate that in strains DM8 and DM20 the integration of the plasmid into the chromosome occurred by a single cross-over recombination event (Fig. 1b).

We also analysed the chromosomal structure of four $\mathrm{Spc}^{\mathrm{R}}$ $\mathrm{MRP}^{-}$mutants obtained after electrotransformation of strain D282 with pMR17. As expected, DNA from all four mutant strains hybridized with the $s p c^{\mathbf{R}}$ gene (data not shown). DNA from strain D282 contained the $2840 \mathrm{bp}$ EcoRI-ClaI fragment that hybridized with the $m r p$ probe (Fig. 3a). In the four mutant strains this $2840 \mathrm{bp}$ hybridizing fragment was absent, and was replaced by the $4040 \mathrm{bp}$ fragment. These data suggest that in all the mutant strains the original $m r p$ gene was replaced by the interrupted $m r p$ gene. However, the intensities of the hybridizing signal differed remarkably between the parent and the mutant strains. Since we applied identical amounts of DNA to the agarose gel (Fig. 3c), we concluded that the mutant strains contained more than one copy of the interrupted mrp gene. One possible explanation for this is that PMR 17 was initially integrated 
(a)

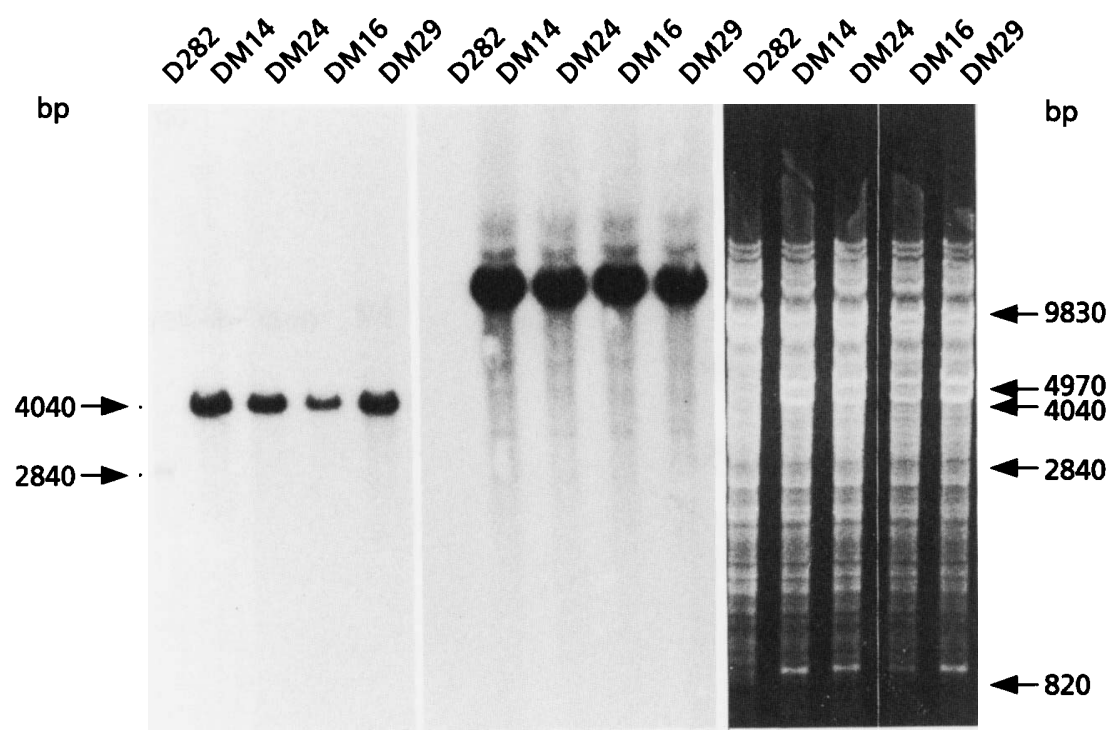

(d)

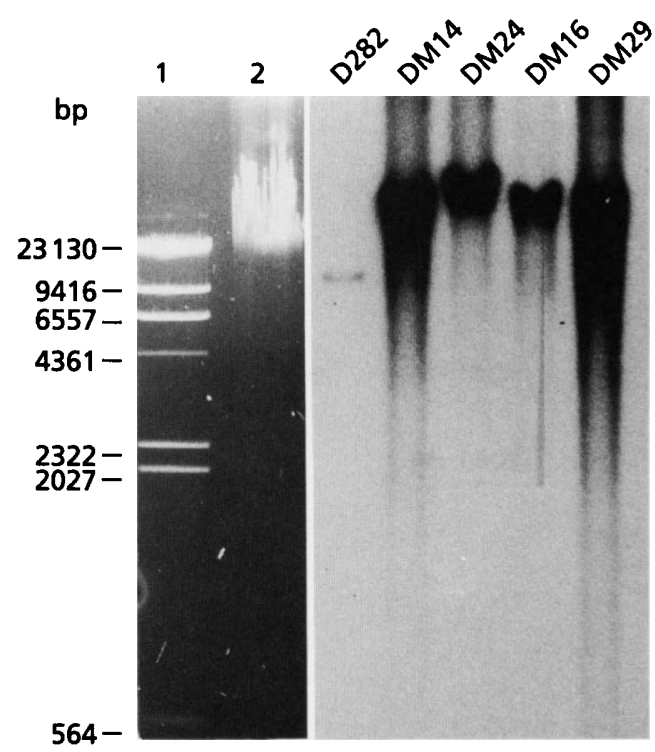

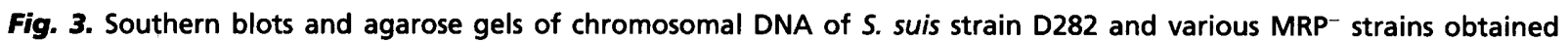
after transformation of strain D282 with pMR17. (a) Southern blot of the gel shown in (c), hybridized with a ${ }^{32} \mathrm{P}$-labelled $1210 \mathrm{bp} \mathrm{Xbal-Scal} \mathrm{fragment} \mathrm{of} \mathrm{the} \mathrm{mrp} \mathrm{gene.} \mathrm{(b)} \mathrm{Southern} \mathrm{blot} \mathrm{of} \mathrm{chromosomal} \mathrm{DNA} \mathrm{digested} \mathrm{with} \mathrm{Scal} \mathrm{and} \mathrm{probed} \mathrm{with}$ 32P-labelled pKUN19. (c) DNA samples digested with EcoRI and Clal on a $0.8 \%$ agarose gel. (d) Lane 1, molecular size markers (lambda DNA digested with HindlII); lane 2, uncut DNA from strain DM14 on a $0.8 \%$ agarose gel. (e) Southern blot of chromosomal DNA digested with Bg/II and hybridized with a ${ }^{32}$ P-labelled 1210 bp Xbal-Scal fragment of the mrp gene. Strain designations are indicated above the lanes.

by a single cross-over recombination and that the integrated plasmid was subsequently amplified (Fig. $1 \mathrm{~b}, \mathrm{c})$. Another possibility is that a multimeric form of the plasmid was integrated in the chromosome by a single cross-over recombination event. After integration of the plasmid as indicated in Fig. 1(b), amplification is possible due to the presence of the 1990 bp repeats which flank the integrated plasmid (Jannière $e t$ al., 1985; Leenhouts $e t$ al., 1990; Fig. 1c). After amplification the chromosome will contain multiple copies of the $4970 \mathrm{bp}, 4040 \mathrm{bp}$ and 820 bp EcoRI-ClaI fragments (Fig. 1c). Amplification of these fragments was visible directly on ethidium-bromidestained agarose gels (Fig. 3c). Integration of the entire plasmid in the chromosome was supported by the observation that in all mutant strains a $9830 \mathrm{bp}$ ScaI fragment strongly hybridized with vector sequences (Figs. $1 \mathrm{c}$ and $3 \mathrm{~b}$ ). Moreover, freely replicating plasmid was not visible in a sample of uncut DNA (Fig. 3d). We also analysed integration of the plasmid in the chromosome after digesting the chromosomal DNA with $\mathrm{Bg} / \mathrm{II}$. This enzyme does not cut within pMR17 nor within the mrp gene. DNA from strain D282 contained a $B g l$ II fragment of about $12 \mathrm{~kb}$ that hybridized with the mrp probe (Fig. $3 e)$. In the mutant strains this fragment was replaced by a larger hybridizing fragment. This strongly indicates that in the mutant strains the plasmid is integrated in the chromosome. All MRP ${ }^{-}$strains lack the original copy of the $m r p$ gene. This indicates that in these strains the original mrp gene was deleted. Recombination between the 2840 bp repeats could explain this event (Fig. 1c).

\section{Characterization of mutants by Western blotting}

We tested whether the MRP and EF proteins were present in the mutant strains by Western immunoblotting. All $\mathrm{MRP}^{-}$strains still produced EF, but lacked the $136 \mathrm{kDa}$ MRP (Fig. 4). Some of the mutant strains (DM8, DM18, DM20, DM24 and DM16) produced a $60 \mathrm{kDa}$ immunoreactive protein. Because we inserted the $s p c^{\mathbf{R}}$ gene into the $m r p$ gene $1860 \mathrm{bp}$ downstream from the translational start site, the $\mathrm{N}$-terminal $60 \mathrm{kDa}$ of MRP was expected to be expressed. Surprisingly, the other mutants (DM13, DM14 and DM29) did not produce the $60 \mathrm{kDa}$ protein. Apparently, expression of the truncated protein was prevented in these strains.

\section{DISCUSSION}

In this paper we describe the introduction of exogenous DNA into $S$. suis type 2 by electrotransformation. With the parameters described, we obtained a transformation efficiency of about $10^{7}$ transformants per $\mu \mathrm{g}$ DNA. Before this, efficient transformation had not been described for $S$. suis. Recently, conjugational transfer of antibiotic-resistance markers between $S$. suis strains was reported (Stuart et al., 1992). The efficiency of transfer, however, was very low.

Also, plasmids replicating in $S$. suis had not previously been described. We electrotransformed $S$. suis cells with the pWVO1-based broad-host-range vectors and demonstrated that they are able to replicate in $S$. suis type 2 . 


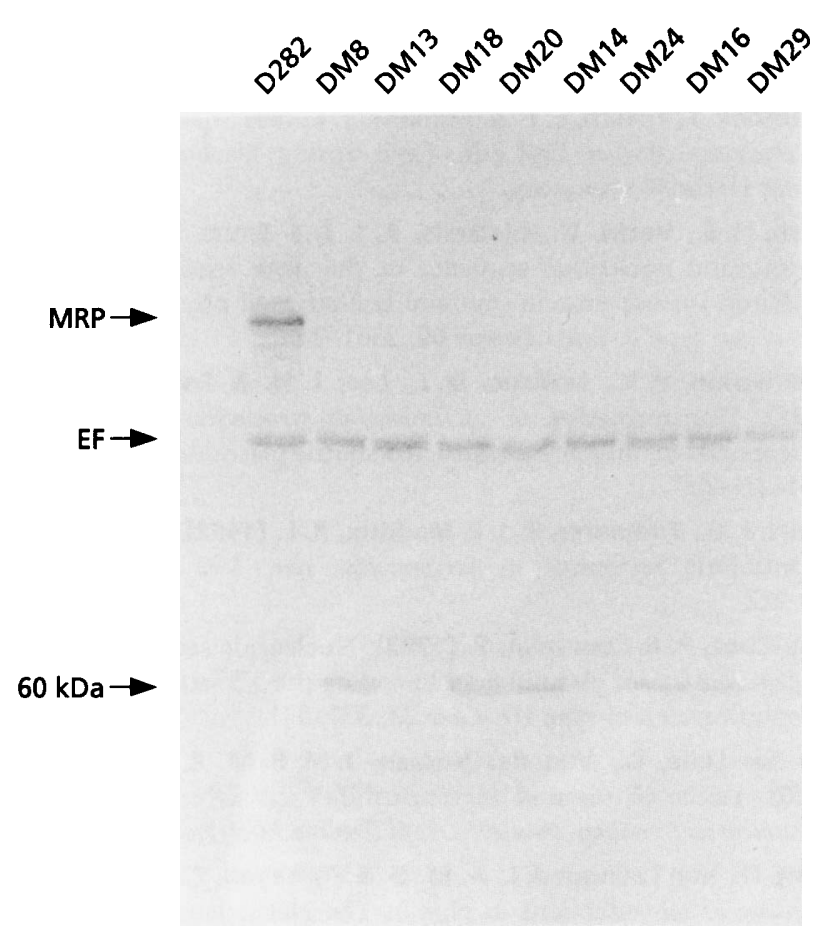

Fig. 4. Western blots of proteins present in culture supernatants of $S$. suis type 2 strain D282 and several MRPmutants screened with anti-MRP and anti-EF polyclonal antibodies (Vecht et al., 1993).

pWVO1 was originally isolated from Lactococcus lactis subsp. cremoris Wg2 (Kok et al., 1984). The plasmid replicates in a large variety of Gram-positive bacteria, including all species of lactic acid bacteria, various streptococci, several Bacillus species, Enterococcus faecalis, Staphylococcus aureus (Kok et al., 1984; Kok, 1991) and Clostridium acetobutylicum (Williams et al., 1990). It also replicates in E. coli (Bron, 1990; Kok et al., 1984). During the last few years, a series of small versatile pWVO1derived vectors has been constructed (Kok, 1991). Because these plasmids also replicate in $S$. suis type 2, recombinant DNA technology can now easily be applied to this organism.

In the present studies we have also inactivated the $m r p$ gene in the chromosome of $S$. suis type 2 . The protein encoded by this gene was previously shown to be associated with virulence of $S$. suis type 2 for young pigs (Vecht et al., 1991, 1992). Double as well as single crossover integrations were obtained. The type of integrant obtained was apparently affected by the level of expression of the $s p c^{\mathrm{R}}$ gene. Double cross-over recombination events were found only if we used plasmids in which the $s p c^{\mathrm{R}}$ gene and the gene in which it was inserted were transcribed in the same direction. A likely explanation for this observation is that in this case the expression of a single copy of the $s p c^{\mathbf{R}}$ gene was increased to a level sufficient to cause resistance to spectinomycin. In contrast, if the $s p c^{\mathbf{R}}$ gene and the gene in which it was inserted were transcribed in opposite directions, we found that the mutant strains contained multiple copies of the inactivated gene in the chromosome. Clearly, in this case the amount of the $s p c^{\mathrm{R}}$ gene product was increased by amplification. If we used plasmids in which the $s p c^{\mathbf{R}}$ gene and the $m r p$ gene were transcribed in opposite directions, transformants were only obtained after an incubation period of $40 \mathrm{~h}$ at $37^{\circ} \mathrm{C}$. Therefore, the slow growth of the transformants seems to be associated with amplification of the $s p c^{\mathbf{R}}$ gene product, which is necessary to enable the cells to grow on selective plates. Amplification is commonly observed after integration of plasmid DNA via a single cross-over event (Jannière et al., 1985; Leenhouts et al., 1990). After integration of plasmids by single cross-over recombination, the chromosome will initially contain the inactivated copy as well as the original copy of the gene. Most of our mutant strains, however, lacked the original copy of the gene. Therefore, those mutants could be the result of a single cross-over integration and subsequent amplification which was followed by deletion of the original gene. This deletion most probably resulted from recombination between the repeats flanking this gene. Alternatively, these mutant strains could be the result of a double cross-over recombination event with a multimeric plasmid. This will result in the deletion of the original gene and can be followed by amplification of the inactivated genes.

Although they did not produce MRP, some mutant strains (DM8, DM20) still seemed to contain a copy of the original $m r p$ gene. We do not know the reason for this observation. A possible explanation is that mutations in the gene, not detectable by Southern hybridizations, prevented the production of the proteins. A second mutation could also explain the fact that mutants DM13, DM14 and DM29 did not produce the $\mathrm{N}$-terminal $60 \mathrm{kDa}$ part of the MRP protein, which was expectd to be synthesized by the inactivated $m r p$ genes.

With the availability of efficient transformation, chromosomal integration and gene replacement systems in $S$. suis type 2 , the role of potential virulence factors in the pathogenesis of this organism can be studied. More specifically, in addition to the $\mathrm{MRP}^{-}$mutants, we will construct $\mathrm{EF}^{-}$mutants and $\mathrm{MRP}^{-} \mathrm{EF}^{-}$mutants and test their virulence after experimental infections in pigs. This should answer the question whether MRP and EF play a role in the pathogenesis of $S$. suis type 2 .

\section{REFERENCES}

Arends, J. P. \& Zanen, H. C. (1988). Meningitis caused by Streptococcus suis in humans. Rev Infect Dis 10, 131-137.

Bron, S. (1990). Plasmids. In Molecular Biology Methods for Bacillus, pp. 75-174. Edited by C. R. Harwood \& S. M. Cutting. Chichester: John Wiley.

Clifton-Hadley, F. A. (1983). Streptococcus suis type 2 infections. $\mathrm{Br}$ $V$ et $J 139,1-5$.

Dower, W. J., Miller, J. F. \& Ragsdale, C. W. (1988). High efficiency transformation of $E$. coli by high voltage electroporation. Nucleic Acids Res 16, 6127-6145.

Dunny, G. M., Lee, L. N. \& LeBlanc, D. J. (1991). Improved electroporation and cloning vector system for Gram-positive bacteria. Appl Environ Microbiol 57, 1194-1201. 
Holo, H. \& Nes, I. F. (1989). High-frequency transformation, by electroporation, of Lactococcus lactis subsp. cremoris grown with glycine in osmotically stabilized media. Appl Environ Microbiol 55, 3119-3123.

Horinouchi, S. \& Weisblum, B. (1982). Nucleotide sequence and functional map of pC194, a plasmid that specifies inducible chloramphenicol resistance. $J$ Bacteriol 150, 815-825.

Jannière, L., Niaudet, B., Pierre, E. \& Ehrlich, S. D. (1985). Stable gene amplification in the chromosome of Bacillus subtilis. Gene 40, $47-55$.

Kok, J. (1991). Special purpose vectors for lactococci. In Genetics and Molecular Biology of Streptococci, Lactococci and Enterococci, pp. 97-102. Edited by G. M. Dunny, P. P. Cleary \& L. L. McKay. Washington, DC: American Society for Microbiology.

Kok, J., Van der Vossen, J. M. B. M. \& Venema, G. (1984). Construction of plasmid cloning vectors for lactic streptococci which also replicate in Bacillus subtilis and Escherichia coli. Appl Environ Microbiol 48, 726-731.

Konings, R. N. H., Verhoeven, E. J. M. \& Peeters, B. P. H. (1987). pKUN vectors for the separate production of both DNA strands of recombinant plasmids. Methods Envymol 153, 12-34.

Laemmli, U. K. (1970). Cleavage of structural proteins during the assembly of the head of T4. Nature 227, 680-685.

LeBlanc, D. J., Lee, L. N. \& Inamine, J. M. (1991). Cloning and nucleotide base sequence analysis of a spectinomycin adenyltransferase $\mathrm{AAD}(9)$ determinant from Enterococcus faecalis. Anticrob Agents Chemother 35, 1804-1810.

Leenhouts, K. J., Kok, J. \& Venema, G. (1990). Stability of integrated plasmids in the chromosome of Lactococcus lactis. Appl Environ Microbiol 56, 2726-2735.

Leenhouts, K. J., Kok, J. \& Venema, G. (1991). Replacement recombination in Lactococcus lactis. J Bacteriol 173, 4794-4798.

Messing, J. (1979). A multipurpose cloning system based on the single-stranded DNA bacteriophage M13. In Recombinant DNA Technical Bulletin (NIH Publication no. 79-99, 2, no. 2), pp. 43-48. Bethesda, MD: National Institutes of Health.

Messing, J. (1983). New M13 vectors for cloning. Methods Enzymol 101, 20-78.

Miller, J. (1972). Experiments in Molecular Genetics. Cold Spring Harbor, NY: Cold Spring Harbor Laboratory.

Miller, J. F., Dower, W. J. \& Tompkins, L. S. (1988). High voltage electroporation of bacteria : genetic transformation of Campylobacter jejuni with plasmid DNA. Proc Natl Acad Sci USA 85, 856-860.

Perez-Martinez, G., Kok, J., Venema, G., van Dijl, J. M., Smith, H.
\& Bron, S. (1992). Protein export elements from Lactococcus lactis. Mol \& Gen Genet 234, 401-411.

Sambrook, J., Fritsch, E. F. \& Maniatis, T. (1989). Molecular Cloning: a Laboratory Manual, 2nd edn. Cold Spring Harbor, NY: Cold Spring Harbor Laboratory.

Smith, H. E., Vecht, U., Gielkens, A. L. J. \& Smits, M. A. (1992). Cloning and nucleotide sequence of the gene encoding the 136 kilodalton surface protein (muramidase-released protein) of Streptococcus suis type 2. Infect Immun 60, 2361-2367.

Sreenivasan, P. K., LeBlanc, D. J., Lee, L. N. \& Fives-Taylor, P. (1991). Transformation of Actinobacillus actinomycetemcomitans by electroporation, utilizing constructed shuttle plasmids. Infect Immun 59, 4621-4627.

Stuart, J. G., Zimmerer, E. J. \& Maddux, R. L. (1992). Conjugation of antibiotic resistance in Streptococcus suis. Vet Microbiol 30, 213-222.

Trieu-Cuot, P. \& Courvalin, P. (1983). Nucleotide sequence of the Streptococcus faecalis plasmid gene encoding the $3^{\prime} 5^{\prime}$-aminoglycoside phosphotransferase type III. Gene 23, 331-341.

Van der Lelie, D., Van der Vossen, J. M. B. M. \& Venema, G. (1988). Effect of plasmid incompatibility on DNA transfer to Lactococcus lactis subsp. cremoris. Appl Environ Microbiol 54, 865-871.

Vecht, U., Van Leengoed, L. A. M. G. \& Verheyen, E. R. M. (1985). Streptococcus suis infections in pigs in The Netherlands (part one). Vet Quart 7, 315-321.

Vecht, U., Arends, J. P., Van der Molen, E. J. \& Van Leengoed, L. A. M. G. (1989). Differences in virulence between two strains of Streptococcus suis type 2 after experimentally induced infection of newborn germfree pigs. Am J Vet Res 50, 1037-1043.

Vecht, U., Wisselink, H. J., Jellema, M. L. \& Smith, H. E. (1991). Identification of two proteins associated with virulence of Streptococcus suis type 2. Infect Immun 59, 3156-3162.

Vecht, U., Wisselink, H. J., Van Dijk, J. E. \& Smith, H. E. (1992). Virulence of Streptococcus suis type 2 strains in newborn germfree pigs depends on phenotype. Infect Immun 60, 550-556.

Vecht, U., Wisselink, H. J., Annakotta, J. \& Smith, H. E. (1993). Discrimination between virulent and nonvirulent Streptococcus suis type 2 strains by enzyme-linked immunosorbent assay. Vet Microbiol 43, 71-82.

Williams, D. R., Young, D. I. \& Young, M. (1990). Conjugative plasmid transfer from Escherichia coli to Clostridium acetobutylicum. J Gen Microbiol 136, 819-826.

Received 2 June 1994; revised 23 August 1994; accepted 6 September 1994. 